DOI https://doi.org/10.30525/978-9934-588-91-4-19

\title{
УКРАЇНСЬКІ ЖУРНАЛІСТИ У США ЩОДО ГОЛОДОМОРУ В УКРАЇНІ 1932-33 РОКІВ (ЗА МАТЕРІАЛАМИ ГАЗЕТИ «СВОБОДА»)
}

\author{
Сидун I. B. \\ кандидат історичних наук, \\ завідувач кафедри періодичної преси та медіаредагування \\ Одеського начіонального університету імені I. I. Мечникова \\ м. Одеса, Україна
}

Сьогодні, незважаючи на відкритість архівів, наукові дослідження, які розкривають страшний злочин проти українців радянської влади, а саме Голодомор 1932-33 років багато питань $є$ відкритими.

Величезну роль у даний період відіграли українці за кордоном, а саме ті хто мав стосунок до засобів масової інформації. Окремі науковці, такі як О. Хімяк, Л. Біловус, Я. Папуга, О. Ковальчук досліджували еміграційну пресу США та Канади. Проте, висвітлення теми Голодомору в українських еміграційних виданнях потребує комплексного дослідження.

Зокрема, недооціненим в наукових працях $є$ вклад українських емігрантів у США, які невтомно працювали на підтримку та захист співвітчизників на рідній землі. Показовим є приклад кореспондентів газети «Свобода» у той період. Окрім того, що вони збираючи максимально доступну інформацію, намагаючись не пропустити жодного важливого свідчення висвітлювали ту страшенну біду, яка спіткала українців, у власних матеріалах, вони займалися збором коштів аби не тільки інформаційно, а й матеріально допомогти землякам. Редакція постійно закликала допомогти своїм співвітчизникам матеріально, зверталася до інших видань з метою поширення інформації. Зокрема, повідомлялося, що при Українській православній церкві у США було проведено збір пожертвувань для голодуючих Гуцульщини [1]. Висвітлена підтримка протестів проти голоду в Україні $[2,3]$. Наявні звернення до президента США Т. Рузвельта, щоби той допоміг у вирішені проблеми [4].

Загалом у матеріалах були наведені факти, які доводять наявність голоду на українських землях, спроби спростувати комуністами цю інформацію, допомога інших країн у подоланні цієї катастрофи. Вражали статті 3 аналізом щодо причин голоду. В більшості 3 них відображено не тільки скрутність положення, але спроба знайти шляхи виходу із такого положення. 
В основному інформація щодо стану країни була отримана від очевидців, зарубіжних кореспондентів, листів з України тощо. Окрім цього, редакція газети передруковувала багато матеріалів з різних закордонних видань, чим показувала ставлення французької [5], чеської [6, 7], швейцарської [8], австрійської [9, 10] та німецької спільноти [11] до ситуації в Україні. В газеті була навіть окрема рубрика «Чужа преса», в якій прослідковується значна зацікавленість та стурбованість Європи щодо даної проблеми. Таким чином, редакція демонструвала світу, що українці за кордоном не єдині у власних прагненнях вирішити ситуацію, допомогти Україні, а що наявне бажання влади та громадян США та європейських країн розібратися та вплинути на дії радянської влади.

\section{Література:}

1. Рибакова А. На голодуючих Гуцулів у Ріднім Краю. Рубрика «Як ми помагаємо рідному краєви». Свобода (США). Ч. 129. 4 червня 1932. URL: http://www.svoboda-news.com/arxiv/pdf/1932/Svoboda-1932129.pdf

2. «Голодовий марш». Свобода (США). Ч. 293. 16 грудня 1932. URL: http://www.svoboda-news.com/arxiv/pdf/1932/Svoboda-1932-293.pdf

3. Українське зорганізоване жіноцтво Америки протестує проти насильного виголодження України Червоною Москвою. Свобода (США). Ч. 276. 27 листопада 1933. URL: http://www.svoboda-news.com/arxiv/pdf/1933/Svoboda-1933-276.pdf

4. 3 Свропи підтримують домагання американських українців. Свобода (США). Ч. 276. 27 листопада 1933. URL: http://www.svoboda-news.com/arxiv/pdf/1933/Svoboda-1933-276.pdf

5. Трагедія над Дністром. Свобода (США). Ч. 124. 28 травня 1932. URL: http://www.svoboda-news.com/arxiv/pdf/1932/Svoboda-1932-124.pdf

6. Протест української жіночої національної ради в Празі проти подій на річці Дністрі. Свобода (США). Ч. 108. 10 травня 1932. URL: http://www.svoboda-news.com/arxiv/pdf/1932/Svoboda-1932-108.pdf

7. Україніка в чеськім пресі. Свобода (США). Ч. 39. 17 лютого 1933. URL: http://www.svoboda-news.com/arxiv/pdf/1933/Svoboda1933-039.pdf

8. Протест українських журналістів проти розстрілів на Дністрі. Свобода (США). Ч. 100. 29 квітня 1932. URL: http://www.svoboda-news.com/arxiv/pdf/1932/Svoboda-1932-100.pdf

9. Кардинал Ініцер знову відзивається у справі допомоги голодуючій Україні. Свобода (США). Ч. 281. 4 грудня 1933. URL: http://www.svoboda-news.com/arxiv/pdf/1933/Svoboda-1933-281.pdf

10. Міжнародна конференція в справі допомоги Україні. Свобода (США). Ч. 294. 19 грудня 1933. URL: http://www.svobodanews.com/arxiv/pdf/1933/Svoboda-1933-294.pdf 
11. Німеччина й Европейський Схід. Свобода (США). Ч. 282. 5 грудня 1933. URL: http://www.svoboda-news.com/arxiv/pdf/1933/Svoboda1933-282.pdf

DOI https://doi.org/10.30525/978-9934-588-91-4-20

\title{
ДО ПИТАННЯ НАУКОВО-ГРОМАДСЬКОЇ ДІЯЛЬНОСТІ ХРИСАНФА ЯЩУРЖИНСЬКОГО (1852 - 1920-ТI РР.)
}

\author{
Силка О. 3. \\ доктор історичних наук, доцент, \\ професор кафедри гуманітарних дисииплін \\ Начіонального університету харчових технологій \\ м. Київ, Украӥна \\ Синявська Л. I. \\ доктор історичних наук, професор, \\ професор кафедри історії Украӥни \\ Черкаського начіонального університету імені Богдана Хмельниџького \\ м. Черкаси, Україна \\ Мазур О. О. \\ кандидат історичних наук, дочент, \\ доцент кафедри історії України \\ Черкаського національного університету імені Богдана Хмельницького \\ м. Черкаси, Україна \\ Коваленко А. О. \\ архіваріус загального відділу \\ Черкаського національного університету імені Богдана Хмельницького \\ м. Черкаси, Украӥна
}

Донедавна ім’я Хрисанфа Петровича Ящуржинського (1852-1923), як і багатьох інших діячів науки, було забуте. Однак, його діяльність як фольклориста, археолога, історика й краєзнавця залишила помітний внесок в українській історичній науці.

Вперше систематичні відомості про життєвий та творчий шлях $\mathrm{X}$. Ящуржинського були надруковані на сторінках багатотомного енциклопедичного видання видавців Ф. Брокгауза та I. Ефрона у 1904 р. За часи радянської влади діяльність Х. Ящуржинського, на відміну від історіографічної характеристики його робіт, не потрапляла у поле зору 